\title{
A study of Serum Soluble CD40 Ligand level and its correlation with serum CK-MB and lipid profile in patients with acutecoronary syndrome
}

\author{
M. Manonmani ${ }^{1, *}$, V. Kuzhandai Velu ${ }^{2}$, Manimekalai $K^{3}$ \\ ${ }^{1}$ Assistant Professor, Dept. of Biochemistry, Government Sivagangai, Medical College \& Hospital, Sivagangai, Tamil Nadu, \\ ${ }^{2}$ Tutor, Department of Biochemistry, ${ }^{3}$ Professor \& HOD, Dept. of Pharmacology, Mahatma Gandhi Medical College \& Research \\ Institute, Pillaiyarkuppam, Puducherry, India
}

*Corresponding Author:

Email: dr.manonmani2011@gmail.com

Received: $18^{\text {th }}$ October, 2017

Accepted: $06^{\text {th }}$ January, 2018

\begin{abstract}
Introduction: Coronary heart disease is an impairment of heart function due to inadequate blood flow to the heart. It is the most common cause of death worldwide. Serum SCD40L is an inflammatory marker. It is released from the platelets as soon as the onset of the chest pain. It is a strong predictor of cardio vascular risk factor.

Objectives: To estimate Serum sCD40Ligand, Serum CK-MB, Serum Lipid Parameters, Serum LDH, and Serum AST levels in patients with ACS.

Materials and Methods: Study group comprised of 50 subjects were admitted in ICCU with ACS. 50 healthy sex and age matched subjects were taken as control groups. Venous blood samples were collected. Serum Soluble CD40Ligand was estimated by ELISA technique, Serum CK-MB estimated by Immunoinhibition method, Serum Lipid profile by enzymatic assay methods. Serum LDH by DKGC method, Serum AST by Modified IFCC method.

Results: There was significant increase in Serum sCD40L(p<0.0001), Serum TC, Serum TGL, Serum LDL-C, Serum VLDL while significant decrease in the Sr. HDL-C levels in the ACS patients compared to control group. There was no significant change in Sr. LDH levels and Sr. AST levels in ACS patients compared to control group. There was a significant positive correlation between Serum sCD40L and Serum CK-MB, Serum TC, Serum TGL, Serum LDL-C, Serum VLDL and a negative correlation between Serum sCD40L and Serum HDL-C while no significant correlation was found between Serum sCD40L with Serum LDH and Serum AST levels.
\end{abstract}

Conclusion: Serum sCD40L can be used as a marker in individuals with Acute Coronary Artery disease.

Keywords: SCD40L, ACS, MI, CK-MB, Lipid Parameters.

\section{Introduction}

Coronary heart disease is defined as cardiac function impairment. There is an inadequate blood flow in the heart compared to its needs and obstructive changes in the coronary circulation. ${ }^{1}$ CHD is a worldwide health epidemic. All over the world it is the commonest cause of death. In USA, European countries, Japan, Singapore, Canada etc, this is the first common cause of death. In India it is one in ten common causes of death. ${ }^{2}$ Epidemics of CHD in United States, began in the early 1920s, in the 1930s in the Britain, still later in several European countries. Worldwide cardiovascular death is about 30 percent. Of which CHD is more than half. ${ }^{3}$ CHD has been classified as Acute Coronary Syndrome, Chronic CHD, and sudden death. Clinically in many ways CHD may present, extending from an asymptomatic finding to unexpected cardiac collapse. Chronic CHD is always secondary to coronary atherosclerosis, leading to coronary blood flow mismatch and adenosine triphosphate homeostasis (imbalance of demand and supply) and coronary ischemia.

Acute coronary syndrome is a unifying term representing a common end result, acute myocardial ischemia. Acute ischemia is usually caused by atherosclerotic plaque rupture, erosion, fissuring, or a combination with superimposed intracoronary thrombosis and is associated with an increased risk of myonecrosis and cardiac death. It encompasses acute myocardial infarction and unstable angina (resulting in ST elevation or non- ST elevation).

ACS in emergency department should be triaged immediately to an area with defibrillation capability and continuous electrocardiographic monitoring. ${ }^{4}$ Diagnosis of ACS at this earlier stage can prevent morbidity and mortality. Along with ECG changes, proteins in the serum like CK-MB, Cardiac Troponin-I $\& \mathrm{~T}, \mathrm{LDH}$ and AST are used to diagnose ACS. ${ }^{5}$ However, in the absence of necrosis these markers are not elevated when measured in the first 2-6 hours following an ischemic event.

Serum sCD40 Ligand - is a type II transmembrane glycoprotein. It is structurally related to Tumor Necrosis Factor -alpha. It is expressed within seconds after platelet activation and it has been shown to be proinflammatory for endothelial cells, which ultimately lead into endothelial dysfunction and atherosclerosis. ${ }^{6}$ Hence in the present study, serum levels of sCD40L were estimated in patients with ACS and the relationship between Serum sCD40L, Serum CKMB and lipid profile were analyzed 


\section{Aims and objectives}

1. To estimate Serum sCD40Llevel in patients with Acute Coronary Syndrome.

2. To correlate the levels of Serum SCD40L with Serum CK-MB which is an effective marker of Acute Coronary Syndrome.

3. To correlate the levels of Serum sCD40L with Lipid profile.

\section{Materials and Methods}

The study was conducted at Thanjavur Medical College Hospital after getting the approval from the ethical committee. In the present study the age group of both study and control group ranged from 35-65years, males

and

females were included and informed consent obtained from them. 50 subjects ( 30 males and 20 females) who were admitted in ICCU of Thanjavur Medical College Hospital with Acute Coronary Syndrome and with clinical findings suggestive of STEMI ( $\mathrm{n}=33)$, NSTEMI $(n=4)$ and unstable angina $(n=13)$ were included in the study group. 50 sex and age matched, healthy individuals were taken as control groups.

\section{Inclusion criteria}

1. Patients admitted with complaint of chest pain within 6 hours of onset, chest pain lasting >30 minutes.

2. Electrocardiographic findings showing abnormal ST-T wave changes (ST segment elevation $>1 \mathrm{~mm}$ in two or more contiguous chest leads or depression or deep symmetrical $\mathrm{T}$ wave inversion).

3. Elevation of serum CK-MB levels more than the normal range.

\section{Exclusion criteria}

1. Anaemia

2. Infection

3. Malignant disease

4. Collagen disease

5. Stroke

6. Cardiac disease other than coronary disease

7. Ballon angioplasty

8. Overt right or left ventricular failure

9. Thrombolytic treatment within three months of study

\section{Blood collection}

Blood samples were collected by venipuncture with strict aseptic precaution as soon as the subjects got admitted as per the inclusion criteria. All the blood samples were centrifuged at $3000 \mathrm{rpm}$ for 10 minutes and serum separated.One part of the serum sample was taken for analysis of CK-MB, Creatinine, and Urea.The remaining part of the serum sample was stored for analysis of soluble $\mathrm{CD} 40 \mathrm{~L}$ at $-40^{\circ} \mathrm{C} 12-14$ hours fasting blood sample was also collected from all subjects during their hospital stay and analysis of total cholesterol, TGL, HDL-C, fasting blood sugar were done.

Estimated parameters from blood samples: The serum sample collected above was used for the estimation of the biochemical parameters. Serum sCD40L was estimated by Enzyme Linked Immuno Sorbant Assay based on the sandwich principle, according to the manufacturer's instructions. ${ }^{7}$ Serum.CK-MB- was estimated by Kinetic immuno inhibition method. ${ }^{8}$ FBG was measured by Trinders method. ${ }^{9}$ Blood Urea was measured according to Urease - GLDH method. ${ }^{10}$ Serum Creatinine was measured according to Jaffes method. ${ }^{11}$

The estimation of Total cholesterol was done by Cholesterol oxidase-PAP, ${ }^{12}$ Serum Triglycerides by GPO-PAP method, ${ }^{13}$ HDL-C by Phosphotungstic acid method $^{14}$ and LDL-C and VLDL-C was calculated as described by Friedewald et al. ${ }^{15}$ Serum LDH was estimated by modified IFCC Method ${ }^{16}$ and Serum AST was by DGKC Method. ${ }^{17}$

\section{Statistical analysis}

Student ${ }^{\prime} \mathrm{t}$ ' test and Chi-square test were employed for the statistical analysis of data. The data were expressed in terms of mean and standard deviation. $P$ value less than 0.05 was taken as significant value. Correlation between the measured parameters was assessed using Pearson's coefficient of correlation.

\section{Results}

Baseline parametersin patients with acute coronary syndrome and control group

Age: Themean age in study group was $55.56 \pm 9.53 \mathrm{yrs}$ and control group was $52.22 \pm 9.41$ yrs. The mean weight in study group was $66.84 \pm 7.75 \mathrm{~kg}$ and control group was $66.60 \pm 7.19 \mathrm{~kg}$. The mean height in study group was $1.63 \pm 0.07 \mathrm{~m}$ and control group was $1.61 \pm$ $0.07 \mathrm{~m}$. The mean BMI in study group was $25.29 \pm$ 2.83 and control group was $25.35 \pm 1.72$. There was no significant difference in age, weight, height and BMI of study group and control group shows the control group taken was age and sex matched. Similarly there was no significant difference in Blood pressure, blood urea levels and Serum creatinine levels in both Study and control group. (Table 1)

Table 1: Baseline characteristics of Study population

\begin{tabular}{|c|l|c|c|}
\hline S.No. & Variables & Control $(\mathbf{n}=\mathbf{5 0})$ & Study $(\mathbf{n}=\mathbf{5 0})$ \\
\hline 1 & Age $(\mathrm{yr})$ & $52.22 \pm 9.41$ & $55.56 \pm 9.53$ \\
\hline 2 & $\mathrm{Wt}(\mathrm{Kg})$ & $66.60 \pm 7.19$ & $66.84 \pm 7.75$ \\
\hline 3 & $\mathrm{Ht}(\mathrm{m})$ & $1.61 \pm 0.07$ & $1.63 \pm 0.07$ \\
\hline
\end{tabular}




\begin{tabular}{|c|l|c|c|}
\hline 4 & BMI & $25.35 \pm 1.72$ & $25.29 \pm 2.83$ \\
\hline 5 & SBP $(\mathrm{mm} \mathrm{Hg})$ & $117.62 \pm 8.00$ & $118.72 \pm 22.18$ \\
\hline 6 & DBP $(\mathrm{mmHg})$ & $78.08 \pm 4.462$ & $82.00 \pm 11.56$ \\
\hline 7 & FBG $(\mathrm{mg} / \mathrm{dl})$ & $93.94 \pm 6.97$ & $110.12 \pm 35.34$ \\
\hline 8 & B. Urea $(\mathrm{mg} / \mathrm{dl})$ & $25.82 \pm 4.60$ & $25.36 \pm 4.65$ \\
\hline 9 & Sr.Creat $(\mathrm{mg} / \mathrm{dl})$ & $0.68 \pm 0.12$ & $0.7 \pm 0.084$ \\
\hline
\end{tabular}

Serum soluble CD40 ligand levels, Serum soluble CK-MB levels, Lipid profile and Liver function parametersbetween patients with acute coronary syndrome and control

Mean serum sCD40L level in ACS patients group was $(4.397 \mathrm{ng} / \mathrm{ml})$ significantly higher than the control group $(1.422 \mathrm{ng} / \mathrm{ml}(\mathrm{P}=0.0001<0.05)$. There wassignificant increase in mean Sr. CK-MB level in ACS group (56.08 \pm $22.58 \mathrm{U} / \mathrm{L})$ comparedto control group $(13.48 \pm 4.047 \mathrm{U} / \mathrm{L})(\mathrm{P}<0.05)$. There was a statistically significant elevation of Sr.TC, Sr. TGL, Sr. VLDL-C, Sr. LDL-C, in ACS group compared to control $(\mathrm{P}=0.0001<0.05)$. The Sr.TClevel was $262.12 \pm 39.72 \mathrm{mg} / \mathrm{dl}$ in ACS patients compared to $166.98 \pm 17.75 \mathrm{mg} / \mathrm{dl}$ in control group. The serum triglycerides level was $185.04 \pm 43.41$ inACS patients compared to $124.76 \pm 23.67 \mathrm{mg} / \mathrm{dl}$ incontrol group. The serum Sr. LDL-C and VLDL-C levels were $191.16 \pm 40.13 \mathrm{mg} / \mathrm{dl}$ and $36.80 \pm 8.75 \mathrm{mg} / \mathrm{dl}$ in ACS patients respectively compared to $98.90 \pm 21.36 \mathrm{mg} / \mathrm{dl}$ and $24.86 \pm 4.75 \mathrm{mg} / \mathrm{dl}$ respectively incontrol group.There was statistically significant decrease in the Sr. HDL-C levels in the study group compared to control group. The serum Sr. HDL-C level was $34.16 \pm 3.88$ $\mathrm{mg} / \mathrm{dl}$ in ACS patients compared to $43.24 \pm 9.90 \mathrm{mg} / \mathrm{dl}$ incontrol group.There was no significant change in $\mathrm{Sr}$. LDH levels and Sr. AST levels in ACS patients compared to control group. (Table 2)

Table 2: showing comparison of Lipid profile parameters between patients with acute coronary syndrome and control group

\begin{tabular}{|c|c|c|c|}
\hline S. No & Variables & $\begin{array}{c}\text { Control } \\
(\mathbf{n = 5 0})\end{array}$ & $\begin{array}{c}\text { ACS patients } \\
(\mathbf{n}=50)\end{array}$ \\
\hline 1 & Sr.sCD40L (ng/ml) & $1.42 \pm 0.139$ & $4.39 \pm 1.90^{*}$ \\
\hline 2 & Sr.CK-MB (U/L) & $13.48 \pm 4.04$ & $56.08 \pm 22.58^{*}$ \\
\hline 3 & Sr.TC $(\mathrm{mg} / \mathrm{dl})$ & $166.98 \pm 17.75$ & $262.12 \pm 39.72^{*}$ \\
\hline 4 & Sr.TGL $(\mathrm{mg} / \mathrm{dl})$ & $124.76 \pm 23.67$ & $185.04 \pm 43.41^{*}$ \\
\hline 5 & Sr.HDL-C $(\mathrm{mg} / \mathrm{dl})$ & $43.24 \pm 9.90$ & $34.16 \pm 3.88^{*}$ \\
\hline 6 & Sr.LDL-C $(\mathrm{mg} / \mathrm{dl})$ & $98.90 \pm 21.36$ & $191.16 \pm 40.13^{*}$ \\
\hline 7 & Sr.VLDL-C $(\mathrm{mg} / \mathrm{dl})$ & $24.86 \pm 4.75$ & $36.80 \pm 8.75^{*}$ \\
\hline 8. & Sr.LDH $(\mathrm{U} / \mathrm{L})$ & $139.00 \pm 11.32$ & $148.86 \pm 22.37$ \\
\hline 9. & Sr. AST $(\mathrm{U} / \mathrm{L})$ & $15.02 \pm 2.93$ & $17.04 \pm 4.62$ \\
\hline
\end{tabular}

Pearson'scorrelation betweenSerum soluble CD40 ligand levels and biochemical parameters in patients of acute coronary syndrome

There was a significant positive correlation between Serum sCD40L and Serum CK-MB, Serum TC, Serum TGL, Serum LDL-C, Serum VLDL and a negative correlation between Serum SCD40L and Serum HDL-C which is statistically significant. No significant correlation was found between Serum sCD40L with Serum LDH and Serum AST. Increased level of sCD40L by $1 \mathrm{ng} / \mathrm{ml}$ leads to increase in level of Sr.CK-MB by $0.777 \mathrm{U} / \mathrm{L}$, Sr.TC by $0.693 \mathrm{mg} / \mathrm{dl}$, Sr. TGL level by $0.596 \mathrm{mg} / \mathrm{dl}$, Sr. LDL-C level by $0.586 \mathrm{mg} / \mathrm{dl}$ and $\mathrm{Sr}$. VLDL-C $0.620 \mathrm{mg} / \mathrm{dl}$ respectively in ACS patients. Increased level of sCD40L by $1 \mathrm{ng} / \mathrm{ml}$ leads to decrease in level of Sr. HDL-C level by $0.637 \mathrm{mg} / \mathrm{dl}$. (Table 3 )
Table 3: $\quad$ Showing Pearson'scorrelation betweenSerum soluble CD40 ligand levels and biochemical parameters in patients of acute coronary syndrome

\begin{tabular}{|c|c|c|}
\hline S. No & Variables & $\begin{array}{c}\text { Pearson } \\
\text { Correlation } \\
\text { coefficient Value }\end{array}$ \\
\hline 1 & Sr.sCD40L (ng/ml) & 1 \\
\hline 2 & Sr.CK-MB (U/L) & $0.777^{* *}$ \\
\hline 1 & Sr.TC (mg/dl) & $0.693^{* *}$ \\
\hline 2 & Sr.TGL (mg/dl) & $0.596^{* *}$ \\
\hline 3 & Sr.HDL-C (mg/dl) & $-0.637^{* *}$ \\
\hline 4 & Sr.LDL-C (mg/dl) & $0.586^{* *}$ \\
\hline 5 & Sr.VLDL-C (mg/dl) & $0.620^{* *}$ \\
\hline 6 & Sr.LDH U/L & -0.082 \\
\hline 7 & Sr.AST U/L & -0.031 \\
\hline
\end{tabular}

\section{Discussion}

The present study was done to evaluate levels of Serum sCD40L in patients with Acute Coronary Syndrome. It is a powerful biochemical inflammatory 
marker. In our study mean age of study group was (55.56 \pm 9.53 years) and that of control group was (52.22 \pm 9.41 years), mean BMI of study group and control group were equal and there was no statistical significance $(25.29 \pm 2.83$ versus $25.35 \pm 1.72, \mathrm{P}>0.05)$.

In the present study mean serum $\mathrm{SCD} 40 \mathrm{~L}$ level of study group was significant higher than the control group $(4.39 \pm 1.90 \mathrm{ng} / \mathrm{ml}$ versus $1.42 \pm 0.139 \mathrm{ng} / \mathrm{ml}$, $\mathrm{P}<0.05)$. This findings are in accordance with the study of Valerio Sanguigni et al, $(4.18 \pm 2.07 \mathrm{ng} / \mathrm{ml}$ in study group versus $2.60 \pm 0.7 \mathrm{ng} / \mathrm{ml}$ in control groups) ${ }^{18}$ Also our study finding was almost consistent with $\mathrm{Pal}$ Aukurst et al study and Priya Gururajan et al study which reported higher levels of Serum SCD40L in ACS patients.

The mean Serum total cholesterol level of $262.12 \pm$ $39.72 \mathrm{mg} / \mathrm{dl}$ in the study group was significantly higher than the control mean Serum cholesterol level of 166.98 $\pm 17.75 \mathrm{mg} / \mathrm{dl}$. This level was slightly higher than the mean level of Serum cholesterol observed in a study done by Priya Gururajan et al, and Mari Luomala et al. ${ }^{19}$

The mean Serum TGL level was $185.04 \pm 43.41 \mathrm{mg} / \mathrm{dl}$ which is significantly higher than the control group mean of $124.76 \pm 23.67 \mathrm{mg} / \mathrm{dl}$. Serum TGL level increases from $90 \mathrm{mg} / \mathrm{dl}$ to $180 \mathrm{mg} / \mathrm{dl}$ is associated with the doubled the incidence of CAD. ${ }^{20-22}$

The mean Serum HDL cholesterol level of $34.16 \pm$ $3.88 \mathrm{mg} / \mathrm{dl}$ in the study group was significantly lower than the control group mean Serum HDL cholesterol level of $43.24 \pm 9.90 \mathrm{mg} / \mathrm{dl}$. Similar values were observed in Yogendrasingh et al, study and demonstrated that low Serum HDL-C increases the risk of CAD.

The mean Serum LDL-C level of $191.16 \pm$ $40.13 \mathrm{mg} / \mathrm{dl}$ in the study group was significantly higher than the control group mean Serum LDL-C level of $98.90 \pm 21.36 \mathrm{mg} / \mathrm{dl}$.Raised Serum LDL cholesterol has been recognized as a primary risk factor for CAD. ${ }^{22}$

The mean level of Serum CK-MB value in the study group was higher than the mean level of Serum CK-MB in control groups $(56.08 \pm 22.58 \mathrm{U} / \mathrm{L}$ versus $13.48 \pm 4.04 \mathrm{U} / \mathrm{L})$, which is statistically significant $(\mathrm{p}<0.05)$.

These variations can be attributed to the modifiable and non-modifiable risk factors of atherosclerosis. Serum LDH and Serum AST values were not that much raised in all age groups.

Pearson coefficient correlation analysis in the study group shows there is a highly significant positive correlation between Serum sCD40L and

Sr.CK-MB $\quad(r=0.777, p<0.01)$ Sr.TC $(r=0.693, p<0.01)$ Sr.TGL $(r=0.569, p<0.01)$ There is negative correlation between Serum $\mathrm{SCD} 40 \mathrm{~L}$ and Serum HDL-C which was statistically significant $(\mathrm{r}=-0.637 \mathrm{p}<0.01){ }^{23,24}$

Serum $\mathrm{sCD} 40 \mathrm{~L}$ contributes to atherosclerotic plaque destabilization and progression of chemokines, growth factors, cytokines and procoagulant factors in various cell types associated with atheroma. For thrombus formation, platelet activation is important, which in turn leads to precipitation of most of the unstable coronary syndromes. Michelson $A D$ et al found that large amounts of Serum sCD40L are produced and released from activated platelets. Yan et al in their study, demonstrated correlation between sCD40L and platelet activation. They also found that in patients with CAD, Serum sCD40L levels indicate an independent increased risk of major adverse cardiovascular events.

\section{Conclusion}

Biochemical markers such as Serum CK-MB, cardiac Troponin-I, and Myoglobin are used in the clinical setting to asses MI. However, elevation of these markers indicate myocardial necrosis and in the absence of necrosis these markers are not elevated. Serum SCD40L is a marker of inflammatory thrombotic activity that is expressed within seconds, after platelet activation. Platelet activation and elevated fibrinogen level are associated with increased risk of Coronary thrombosis which is the gravest complication of atherosclerosis. Since ACS is complicated by both myocardial necrosis and inflammation, assessment of both the processes may allow a better assessment of the disease. Early intervention using anti-inflammatory drugs can be tried to prevent the progression of infarct size. This helps in reducing the morbidity and mortality from acute coronary syndrome.

\section{Limitations of the study}

Serum sCD40L when coupled with coronary angiography would have aided in assessing the severity of coronary stenosis. Analysis of genetic polymorphism in $\mathrm{SCD} 40 \mathrm{~L}$ would have enabled discrimination of various iso forms and their association with $\mathrm{CAD}$

\section{References}

1. Park K. Epidemiology of Chronic Non-Communicable Diseases and Conditions. In: Park. K, editor. Park's text book of preventive social medicine. $20^{\text {th }}$ edition. Jabalbur, India;.M/s Banarsidas Bhanot pub; 2009. p.15-317.

2. Rao B. Prevention of Non- Communicable Diseases.In: Baskara Rao, editer. Text book of Community Medicine; $2^{\text {nd }}$ edition. Hyderabad; Paras Medical Pub;2006.p.162-3.

3. Gaziano TA, Bitton A, Anand S, Abrahams-Gessel S, Murphy A. Growing Epidemic of Coronary Heart Disease in Low- and Middle-Income Countries. Current problems in cardiology. 2010;35(2):72-115.

4. Michael C. Kim/Annapoorna S. Kini/ Valentin Fuster. Definitions of Acute Coronary Syndromes. In: Valentin Fuster, Robert A.O Rourke, Richard A. Walsh, et al, editors. Hurts The Heart.12th edition. New York: Mc Graw Hill medical pub; 2008. p. 1311-2,1316-8.

5. Al-Hadi HA, Fox KA. Cardiac Markers in the Early Diagnosis and Management of Patients with Acute Coronary Syndrome. Sultan Qaboos University Medical Journal. 2009;9(3):231-46. 
6. Santilli F, Basili S, Ferroni P, Davì G. CD40/CD40L system and vascular disease. Int Emergency Med (2007) 2:256.

7. Bereczki D, Nagy E, Pal A, Magyar MT, Balla J. Should soluble CD40 ligand be measured from serum or plasma samples? Arterioscler Thromb Vasc Biol 2003;23:1129-30.

8. Morris SA. Clinical utility of CK-MB determinations in patients who present to the emergency department with continous or resolved chest pain.J Emerg.Med 2000.19(1):21-6.

9. Mcgowan MW, Trinder P. A per-oxidase coupled method for the colorimetric determination of serum triglycerides. Clin Biochem. 1983;29:538.

10. Marsh WH, Fingerhut B, Miller H: Automated and manual direct method for the determination of blood urea. Clin Chem 11:624-627,1965

11. Jaffe M. Uber den niederschlag, welchen pikrinsaure in normalen hrn erzeugt und uber eine neue reaction des kreatinins. Z Physiol Chem. 1886;10:391-400.

12. Lie RF, Schmitz JM, Pierre KJ, Gochman N. Cholesterol oxidase-based determination, by continuous-flow analysis, of total and free cholesterol in serum. Clin Chem. 1976 Oct;22(10):1627-30.

13. Sullivan DR, Kruijswijk Z, West CE, Kohlmeier M, Katan MB. Determination of serum triglycerides by an accurate enzymatic method not affected by free glycerol. Clin Chem. 1985 Jul;31(7):1227-8.

14. Assmann G, Schriewer H, Schmltz G, Hagele E. Quantification of High-Density-Lipoprotein Cholesterol by Precipitation with Phosphotungstic Acid/MgCI2. Clin chemistry 1983;29(12):2026-29.

15. Friedewald WT, Levy RI, Fredrickson DS. Estimation of the concentration of low-density lipoprotein cholesterol in plasma, wthout use of preparative ultracentrifuge. Clin Chem 1972;18:499-502.

16. Recommendations for the measurement of LDH in human serum at 30 c. Ann Biol Chem 1982;40:87.

17. Rec. G SCC (Deutsche Gesellschaft fur klinische chemie); J Clin Chem. Clin Biochem 1972; 10: 182.

18. Ahmed H. Kissebah, Glenn R. Krakoner. Clinical Manifestations of the Metabolic Syndrome.In:Geroge A.Bray, Claude Bouchard, W. P. T. James, editors. Hand Book of Obesity. NewYork: Marcel Dekker Inc;1998. p.604.

19. Luomala M, Paiv Ha, Laaksonen R. Plasma soluble CD40 is related to cholesterol metabolism in patients with moderate hypercholesterolemia. Scandinavian Cardiovascular Journal. 2006;40:280- 84.

20. Rissam HS, Kishore S, Trehan N. Coronary Artery Disease in Young Indians, The Missing Link. Journal, Indian Academy of Clinical Medicine. September 2001;2(3):12831.

21. Lopez J. Carl A. Burtis, Edward R. Ashwood and David E. Bruns (eds): Tietz Textbook of Clinical Chemistry and Molecular Diagnosis (5th edition): Elsevier, St. Louis, USA, 2012, 2238 pp, 909 illustrations. ISBN: 978-1-4160-61649. Indian Journal of Clinical Biochemistry. 2013;28(1):1045.

22. Singh S, Srivastava S, Ahmad S. Is Lipid Tetrad Index the Strongest Predictor of Premature Coronary Artery Disease in North India ?. JIACM. 2010;11(3):175-9.

23. Garlichs CD, John S. Schmeisser A, Stumpf ES. Upregulation of CD40 and CD40 Ligand (CD154) in Patients with moderate hypercholesterolemia.Circulation.2001 Nov 13;104(20):2395-400.

24. Cipollone F, Mezzetti A, Porreca E. Association Between Enhanced Soluble CD40Land Prothrombotic State in
Hypercholesterolemia: Effects of Statin Therapy. Circulation.2002;106:399-402. 